\title{
Laboratory-based Evaluation of The Potential of Beauveria bassiana Crude Metabolites for Mosquito Larvae Annihilation
}

\author{
Bezalwar $\mathrm{PM}^{* 1}$, Gomashe $\mathrm{AV}^{2}$ and Gulhane $\mathrm{PA}^{3}$ \\ *II Department of Microbiology, S.S.E.S.A's Science College, Congress Nagar,Nagpur-440012 (MS), India). \\ ${ }^{21}$ Department of Microbiology, S.S.E.S.A's Science College, Congress Nagar,Nagpur-440012 (MS), India.) \\ ${ }^{3}$ (Department of Microbiology, S.S.E.S.A's Science College, Congress Nagar,Nagpur-440012 (MS), India.)
}

\begin{abstract}
Malaria is a disease of concern with respect to morbidity and mortality. Intent of the study is to use the metabolite of Beauveria bassiana to control the survival of larvae of malarial parasite. For Dichloromethane extract,20\%, 20\%, 60\% and $100 \%$ larval death occurs after one and half hour for the extract $7.5 \mathrm{mg}, 15 \mathrm{mg}, 22.5 \mathrm{mg}$ and $30 \mathrm{mg}$ respectively whereas, for Chloroform extract 40\%, 60\% and 100\% larval death occurs after one and half hour for $7.5 \mathrm{mg}, 15 \mathrm{mg}$ and $30 \mathrm{mg}$ extract respectively. Dichloromethane and Chloroform extract of Beauveria bassiana showed potential anti-larval activity.
\end{abstract}

Key Words:Malarial parasite, Larvae, Beauveria bassiana, Dichloromethane, Chloroform

\section{Introduction:}

Malaria imposes great socio-economic burden on humanity and with six other diseases (diarrhea, HIV/AIDS, tuberculosis, measles, hepatitis B, and pneumonia), accounts for $85 \%$ of global infectious disease burden. ${ }^{1,2}$ Malaria afflicts $\sim 90$ countries and territories in the tropical and subtropical regions and almost one half of them are in Africa, South of Sahara. About 36\% of the world population (i.e., 2020 million) is exposed to the risk of contracting malaria. ${ }^{3}$ The World Health Organization estimates 300-500 million malaria cases annually, with $90 \%$ of this burden being in Africa. In addition, the estimated annual mortality attributed to malaria ranges from 700,000 to 2.7 million globally and $>75 \%$ of them areAfrican children and expectant mothers. In the Southeastern Asian Region of WHO, of $\sim 1.4$ billion people living in 11 countries (land area, $8,466,600 \mathrm{~km}^{2}$; i.e., $6 \%$ of global area), 1.2 billion are exposed to the risk of malaria, most of whom live in India. ${ }^{13}$ However, Southeast Asia contributed to only 2.5 million cases to the global burden of malaria,of this, India alone contributed $76 \%$ of the total cases. ${ }^{4,5,6}$

The use of biological pesticides such as entomopathogenic fungi is growing in popularity because it is able to alleviate many of the concerns associated with chemical poisons. The use of entemopathogenic fungi have been revised significantly. ${ }^{7-13}$ First, entomopathogenic fungi are found ubiquitously in the soil throughout the world, therefore they would not be considered as "introduced" organisms into the environment. Second, although Beauveria bassiana is considered a broad-spectrum insect pathogen, strains can be developed that are more hosts specific. With research into pathogenicity and strain specificity, it is anticipated that fungal biological control agents can be selected to target specific insect pest. ${ }^{14}$

Beauveria is one of the frequently isolated entomopathogenous fungi with a cosmopolitan distribution. Beauveria bassiana is an ubiquitous saprobe and can be found in soil or decaying plant material, where it grows as multicellular mycelia by absorbing nutrients from the decaying matter. Mosquitoes have been listed as one of the natural host of Beauveria bassiana ${ }^{15}$ Beuveria bassiana is non toxic to mammals, birds, or plants; and its use is not expected to have deleterious effects on human health or the environment. ${ }^{16}$ Conidia of Beauveria bassiana are effective in killing mosquito larvae when applied as conidia dust in breedingsites. Besides infecting larvae, thefungus has also proved to be virulent to adult mosquitoes. ${ }^{17,18,19}$

Recently, theoretical and experimental studies have shown the potential of entomopathogenic fungi as next generation agents for the control of malaria mosquitoes. Currently there are no vaccines against malaria; however, studies have shown the potential for fungal entomopathogens to reduce the spread of this disease. ${ }^{19}$ However, most of this work has focused on targeting adult mosquitoes. Larval control has a convincing history of malaria eradication and recent studies have also shown this approach to be highly effective. ${ }^{1,20,21,22-24}$ It is, therefore, worthwhile to investigate the ability of entomopathogenic fungi Beauveria bassiana to control mosquito larvae. The objective of this study was to assess the efficacy of bioactive compound extracted from Beauveria bassiana by using chloroform and dichloromethane. 


\section{Materials And Methods:}

\subsection{Isolation of Beauveria bassiana:}

The fungus Beauveria bassianawas isolated from soil taken from experimental farms of Panjabrao Deshmukh Krishi Vidyapeeth, Nagpur.The serial dilution method resulted observable growth intoplates of $10^{-3}$, $10^{-4}$ and $10^{-5}$ dilution. Using standard taxonomic keys, monographs, atlases and various websites isolates were characterized, identified and assigned to respective genera and species. White mucoid colonies were suspected as Beauveria bassiana were subcultured on potato dextrose agar. Identification was carried out on the basis of morphological and cultural characteristics. ${ }^{25,26}$

\subsection{Extraction of Bioactive Compound:}

\subsubsection{Dichloromethane Extraction (Set-1):}

Beauveria bassiana was inoculated into Saborauds Dextrose Broth. A $5 \mathrm{ml}$ inoculum $\left(9.75 \times 10^{6}\right.$ spores $/ \mathrm{ml}$ ) was transferred in 5 flasks containing $250 \mathrm{ml}$ Saborauds dextrose broth each. The flasks were kept in orbital shaker at $120 \mathrm{rpm}$ at $25^{\circ} \mathrm{C}$, for 10 days. After incubation fungal mycelial balls were formed in media.The media were pressed through muslin cloth and mycelia were collected. Collected mycelia were soaked in $200 \mathrm{ml}$ methanol for 48 hours. It was filtered through muslin cloth and allowed for evaporation of methanol upto dryness on heating water bath. The $150 \mathrm{ml}$ distilled water was added to the concentrated extract and bioactive compound was extracted with $150 \mathrm{ml}$ dichloromethane. The organic dichloromethane was evaporated on heating in water bath. Dark brown compound so obtained was used for further study.

\subsubsection{Chloroform Extraction (Set-2):}

Beauveria bassiana was inoculated into Saborauds Dextrose Broth. A $5 \mathrm{ml}$ inoculums $\left(10.25 \times 10^{6}\right.$ spores $/ \mathrm{ml}$ ) was transferred in 5 flasks containing $250 \mathrm{ml}$ Saborauds dextrose broth each. The flasks were kept in orbital shaker at $120 \mathrm{rpm}$ at $25^{\circ} \mathrm{C}$, for 10 days. After incubation fungal mycelial balls were formed in media.The media were pressed through muslin cloth and mycelia were collected. Collected mycelia were soaked in $200 \mathrm{ml}$ methanol for 48 hours. It was filtered through muslin cloth and allowed for evaporation of methanol upto dryness on heating water bath. The $150 \mathrm{ml}$ distilled water was added to the concentrated extract and bioactive compound was extracted with $150 \mathrm{ml}$ chloroform. The organic layer of chloroform was evaporated on heating water bath. Brownish-yellow compound obtained was used for further study. ${ }^{27}$

\subsection{Field collection of mosquito larvae:}

Mosquito larvae were collected as larvae from breeding sites in Nagpur city(MS), India in the July and August (2012) months of monsoon. Breeding sites varied from tyre tracks, irrigation pools, and shallow water to open concrete water tanks. Larvae were collected using the dipping method with the aid of copper ladle, transferred into plastic jars with perforated lids for ventilation and transported to the laboratory for rearing.

\subsection{Weather Conditions in the study area:}

Nagpur has tropical wet and dry climate with dry conditions prevailing for most of the year. It receives an annual rainfall of $1,205 \mathrm{~mm}$ (47.44 inches) from monsoon rains during June to September. Summers are extremely hot, lasting from March to June. On record temperature ranges highest $47.9^{\circ} \mathrm{C}$, to lowest $3.9^{\circ} \mathrm{C}$.

\subsection{Laboratory rearing of mosquitoes:}

Larvae were cultured in plastic containers, $5 \mathrm{~cm}$ height by $27 \mathrm{~cm}$ width by $36 \mathrm{~cm}$ long with a large surface area and a water depth not more than $4 \mathrm{~cm}$ at $25 \pm 2^{\circ} \mathrm{C}$ and $70-75 \%$ relative humidity. A 12 hours light and dark cycle was maintained ${ }^{28}$. A $20-25 \mathrm{mg}$ farex was provided as larval feed every 24 hours in each of the larval rearing basins.

\subsection{Antimosquito larval activity test:}

2.5.1 Set-1:Total 8 beakers containing $10 \mathrm{ml}$ distilled water and 10 mosquito larvae were taken. Out of them 4 were used as control and 4 were used as experimental. The $100 \mathrm{mg}$ extract containing bioactive compound was dissolved in $2 \mathrm{ml}$ methanol i.e., $50 \mathrm{mg}$ per $\mathrm{ml}$. From this $1.5 \mathrm{ml}$ extract was taken and dissolved in $8.5 \mathrm{ml}$ distilled water i.e., $7.5 \mathrm{mg} / \mathrm{ml}$. Then it was tested against mosquito larvae in various concentrations such as $1 \mathrm{ml}$ $-7.5 \mathrm{mg}, 2 \mathrm{ml}-15.0 \mathrm{mg}, 3 \mathrm{ml}-22.5 \mathrm{mg}$ and $4 \mathrm{ml}-30.0 \mathrm{mg}$. For control 15\% methanol was prepared and applied as $1 \mathrm{ml}, 2 \mathrm{ml}, 3 \mathrm{ml}$ and $4 \mathrm{ml}$.

2.5.2 Set-2:Total 8 beakers containing $10 \mathrm{ml}$ distilled water and 10 mosquito larvae were taken. Out of them 4 were used as control and 4 were used as experimental. The $375.4 \mathrm{mg}$ extract containing bioactive compound was dissolved in 5ml DMSO. From this $1 \mathrm{ml}$ extract was taken and dissolved in $9 \mathrm{ml}$ of distilled water i.e., 
concentration of extract is $7.5 \mathrm{mg} / \mathrm{ml}$. Then it was tested against mosquito larvae in various concentrations such as $1 \mathrm{ml}-7.5 \mathrm{mg}, 2 \mathrm{ml}-15.0 \mathrm{mg}, 3 \mathrm{ml}-22.5 \mathrm{mg}$ and $4 \mathrm{ml}-30.0 \mathrm{mg}$. For control $1 \mathrm{ml}$ DMSO was dissolved in $9 \mathrm{ml}$ distilled water and applied as $1 \mathrm{ml}, 2 \mathrm{ml}, 3 \mathrm{ml}$ and $4 \mathrm{ml}^{29}$

\section{Results:}

In the present study it was planned to have an insight into the sourcing of entomopathogenic fungi from nature. Entomopathogenic fungi can be found infecting living as well as dead insects in a variety of habitats. So an exercise was carried out to isolate Beauveria bassiana, laboratory culturing and metabolite extraction, and to evaluate its activity against field collected mosquito larvae. The fungus Beauveria bassiana was isolated successfully from soil. In set-1, total extract obtained was $100 \mathrm{mg}$. The extract was applied to test antimosquito larval activity were $7.5 \mathrm{mg}, 15 \mathrm{mg}, 22.5 \mathrm{mg}$ and $30 \mathrm{mg}$. Till the first half hour there was no death in the beaker. After first half hour the movements of larvae become slower in the beaker containing $15 \mathrm{mg}$ and $22.5 \mathrm{mg}$ extract and 1 larva died in the beaker. After $1 \mathrm{hr}$ the movement of larvae in all the beakers slower down and larval death occurs in all four beakers. There was $20 \%, 20 \%, 60 \%$ and $100 \%$ larval death occurs after one and half hour in the beakers containing $7.5 \mathrm{mg}, 15 \mathrm{mg}, 22.5 \mathrm{mg}$ and $30 \mathrm{mg}$ dichloromethane extract respectively, except, in set-4 with $4 \mathrm{ml}$ of dichloromethane extract at $11: 35$ am and $1 \mathrm{ml}$ extract at 12:35pm showed slow activity whereas, at 1:05pm set-3 with $4 \mathrm{ml}$ extract showed $90 \%$ larval death. In set-1 beaker containing $30 \mathrm{mg}$ dichloromethane extract showed $100 \%$ positive mosquito larvicidal effect within one and half hour (Table 1) (Fig.1).

In set-2, total extract obtained was $375 \mathrm{mg}$. The extract was applied to test antimosquito larval activity were $7.5 \mathrm{mg}, 15 \mathrm{mg}, 22.5 \mathrm{mg}$ and $30 \mathrm{mg}$. Till the first hour there was no larval death in the beaker. After first hour the movements of larvae become slower in all the beakers and 2, 3 and 3 larvae were died in the beaker containing $15 \mathrm{mg}, 22.5 \mathrm{mg}$ and $30 \mathrm{mg}$ extract respectively. After $2 \mathrm{hrs}$ the movement of larvae in all the beakers becomes slower and there was again 2 and 3 larvae died in the beaker containing $15 \mathrm{mg}$ and $30 \mathrm{mg}$ extract respectively. After two and half hour there was 4 more larvae died in the beaker containing $30 \mathrm{mg}$ extract. There was $40 \%, 60 \%$ and $100 \%$ larval death occurs after one and half hour in the beakers containing $7.5 \mathrm{mg}, 15 \mathrm{mg}$ and $30 \mathrm{mg}$ chloroform extract respectively, except set-2 with $4 \mathrm{ml}$ extract at 2:00 pm has given 20\% larval death and at 3:00 pm gives 40\% larval death respectively (Table 2) (Fig. 2).

Interpreting results showed thatthe beakers containing $30 \mathrm{mg}$ chloroform and dichloromethaneextract has given $100 \%$ positive mosquito larvicidal effect within two and half hours.Unusual results in few sets considered to be a false result shown by larvae might be due to physiological defects and low immunity of the larvae.From the results, it can be concluded that fungal extract of Beauveria bassiana containing bioactive components have the ability to kill mosquito larvae.

\section{Discussion:}

The results of this study showed dichloromethane and chloroform extract of Beauveria bassiana have the ability to produce the bioactive compound for inhibiting mosquito larvae which confer to its lethality. In set1 beaker containing $30 \mathrm{mg}$ dichloromethane extract shows $100 \%$ positive mosquito larvicidal effect within one and half hour (Table 1). In set-2, the beakers containing $30 \mathrm{mg}$ chloroform extract shows $100 \%$ positive mosquito larvicidal effect within two and half hours ${ }^{28,30}$ (Table 2). On evaluation of 17 species, LC $_{50}$ values obtained to be in the range of 3-24 $\mu \mathrm{l} / \mathrm{ml}$ against Culexquinquefasciatus $3 \mathrm{rd}$ instar larvae on $48 \mathrm{hrs} .{ }^{31} \mathrm{~A}$ crude extract of tolypin caused $100 \%$ mortality in the larvae of Culex. pipiens and Anopheles maculipennis at a concentration of $11.1 / \mathrm{m} 1 .{ }^{33}$ Bioassay of dichloromethane extract from mycelium of B. bassiana at $100 \mathrm{ppm}$ showed activity against Aedes aegypti larvae. ${ }^{32}$ The extract had Beauvericin and two analogues (Beauvericin A and B). For the study of Beauveria bassiana metabolite extract, $86 \%$ mortality observed with beauvericin in Aedes aegypti larvae after $48 \mathrm{~h}$ exposure at $20 \mathrm{~g} / \mathrm{ml},{ }^{34}$ but only $39 \%$ when half the dose was used $(10 \mathrm{~g} / \mathrm{m} 1$. With LD50 values of 10 to $100 \mathrm{ppm}$ a mixture of $70 \%$ destruxin A and 30\% B from Metarhizium anisopliae was shown to be toxic to mosquito larvae. ${ }^{35}$ Thus, entomopathogenic fungi Beauveria bassiana extracted with suitable solvents are a promising tool for control of larval populations of malaria mosquitoes. These results provide evidence that the entomopathogenic fungus Beauveria bassiana has potential for useas an alternative vector control tool against insecticide-resistant mosquitoes. Many entomopathogenic fungi of the Hyphomycetes are known to produce toxic insect secondary metabolites in nutrient-rich media. Some of these metabolites from Hyphomycetes have been isolated and identified ${ }^{36-39}$ and their chemical structures have been elucidated (e.g. oosporein, beauvericin and beauveriolides). Studies have shown that quantities of these metabolites produced in vivo are usually much less than those secreted in nutrient media. ${ }^{40}$

These mosquito-pathogenic fungi need to be studied further extensively with respectto large-scale production of conidia, the stability of these formulations underlaboratory and field conditions needs to be evaluated. Secondary metabolites have shown promising larvicidal activity, the active fraction needs to be studied in detailand has a potential of commercial exploitation. 


\section{References:}

[1]. G. F. Killeen, U. Fillinger, B. G. J. Knols, Advantages of larval control for African malaria vectors: Low mobility and behavioural responsiveness of immature mosquito stages allow high effective coverage. Malar J., 1, $2002,8$.

[2]. A. V.Kondrachine, Malaria in WHO Southeast Asia Region. Indian J Malariol. 29, 1992, 129-160.

[3]. J. G. Breman, The ears of the hippopotamus: manifestations, determinants and estimation of the malaria burden. Am J Trop Med Hyg 64 (Suppl 1). 2001, 1-11.

[4]. A. Kumar, N. Valecha, T. Jain, A. Dash, Burden of Malaria in India: Retrospective and prospective view. Am J Trop Med Hyg. 77(6), 2007, 69-78.

[5]. C. J. L. Murray, A. D. Lopez, Evidence-based health policy lessons from the Global Burden of Disease Study. Science 274, 1996, 740-743.

[6]. C. J. L. Murray, A. D. Lopez, The Global Burden of Disease 1990-2020: alternative projections of mortality and disability by cause for eight regions. Lancet. 349, 1997, 1498-1504.

[7]. C.W. McCoy, R. A. Samson\&Boucias, D.G. Entomogenous fungi. In: CRC Handbook of natural pesticides; microbial insecticides, Part A entomogenous protozoa and fungi. CRC Press, Boca Raton Fl. 1988, 151-236.

[8]. D.W. Roberts, World picture of biological control of insects by fungi. Mem. InstOswaldo Cruz, 84(111), 1989, 89-100.

[9]. C.W. McCoy, Entomogenous fungi as microbial pesticides. In: New Directions in Biological Control: Alternatives for Suppressing Agricultural Pests and Diseases. (Eds: R.R. Baker \& P.E. Dunn). Alan R. Liss, New York. 1990, 139—159.

[10]. P. Ferron, Pest control by the fungi Beauveria and Metarhizium. In: Microbial Control of Pests and Plant Diseases 1970-80. (Ed. H.D. Burges). Academic Press, London. 1981, 465-482.

[11]. A.E. Hajek\& St. Leger, R.J. Interactions between fungal pathogens and insect host. Ann. Rev. Entomol., 39, 1994, $293-322$.

[12]. A.K. Chamley, Entomopathogenic fungi and their role in pest control. In: The Mycota IV. Environmental and microbial relationships. (Eds.: Wicklow/Soderstrom) Springer-Verlag, Berlin, 1997, 185-198.

[13]. H.E. Roy, D.C. Steinkraus, J. Eilenberg, A.E. Hajek \& J.K. Pell, Bizarr interactions and endgames: Entomopathogenic fungi and their arthropod hosts. Annu. Rev. Entomol. 51, 2006, 331-57.

[14]. P. A. Hancock, M. B. Thomas, H. C. J. Godfray, An age-structured model to evaluate the potential of novel malaria-control interventions: A case study of fungal biopesticide sprays, Proceedings of the Royal Society B: Biological Sciences. 276, 2009, 7180 .

[15]. St-Germain, G., and Summerbell, R., Identifying Filamentous Fungi- A Clinical Laboratory Handbook. Star Publishing Company, Belmont, California. 1996

[16]. EPA. Biopesticide Fact Sheet: Beauveria bassiana strain ATCC. 74040, 2000 (128818)

[17]. F. V. Annabel, Howard, Constantianus, J. M Koenraadt, MaritFarenhorst, Bart, G. H Knols and Willem., Prethroid resistance in Anopheles gambie leads to increased susceptibility to the entomopathogenic fungi Metarhizium anisopliae and Beauveria bassiana. Malar J., 9, 2010, 168.

[18]. C. Wang and E. Janine, Isolation and evaluation of Beauveria bassiana for control of Coptotermes formosanus and Reticulitermes flavipes (Isoptera: Rhinotermitida) Sociobiology. 41(1), 2002, 1-13.

[19]. E. J. Scholte, K. Ng'habi, J. Kihonda, W. Takken, K. Paaijmans, S. Abdulla, G. F. Killeen, B. G. J. Knols, An entomopathogenic fungus for control of adult African malaria mosquitoes. Science. 308, 2005, 1641-1642.

[20]. U. Fillinger, B. Ndenga, A. Githeko, S. W. Lindsay, Integrated malaria vector control with microbial larvicides and insecticidetreated nets in western Kenya: A controlled trial. Bulletin of the World Health Organization. 87, 2009, 655-665.

[21]. G. F. Killeen, U. Fillinger, I. Kiche, L. C. Gouagna, B. G. J. Knols, Eradication of Anopheles gambiae from Brazil: lessons for malaria control in Africa. Lancet Infect Dis. 2, 2002, 618-627.

[22]. F. L. Soper, Paris green in the eradication of Anopheles gambiae: Brazil, 1940; Egypt, 1945. Mosquito news. 26, 1966, $470-476$.

[23]. W. Takken, W. B. Snellen, J. P. Verhave, B. G. J., Knols, Atmosoedjono S: Environmental measures for malaria control in Indonesia - an historical review on species sanitation. Wageningen Agricultural University Papers. 1990, 90-97.

[24]. J. Utzinger, Y. Tozan, B. H. Singer, Efficacy and cost-effectiveness of environmental management for malaria control. Trop Med Int Health. 6, 2001, 677-687.

[25]. P. Roberts and S. Evans, The book of fungi-A life size guide to six hundred species around the world. The University of Chicago Press, Chicago. 22, 2000, 548.

[26]. S. A. Safavi, Isolation, identification and pathogenicity assessment of a new isolate of entomopathogenic fungus, Beauveria bassiana. Iran. Journal of Plant Protection Research. 50(2), 2010, 158-163.

[27]. N. E. Jenkins, G. Heviefo, J. Langewald, A. J. Cherry, C. J. Lomer, Development of mass production technology for aerial conidia of mitosporic fungi for use as mycopesticides. Biocontrol News and Information. 19, 1998, 21-31.

[28]. O. A. Achonduhand P. R. Tondje, First report of pathogenicity of Beauveria bassiana RBL1034 to the malaria vector, Anopheles gambiaes.1. (Diptera; Culicidae) in Cameroon. African Journal of Biotechnology. 7(8), 2008, 931-935.

[29]. J. George, N. E. Jenkins, S. Blanford, M. B.Thomas, T. C. Baker, Malaria mosquitoes attracted by fatal fungus. Plos One,8(5), 2013, 1-8.

[30]. C. K. Kikankie, B. D. Brooke,B. G. J. Knols, L. L. Koekemoer, M. Farenhorst, R. H. Hunt, M. B. Thomas,M. Coetzee, The infectivity of the entomopathogenic fungus Beauveriabassiana to insecticide-resistant and susceptible Anopheles arabiensis mosquitoes at two different temperatures. Malar. J. 9, 2010, 71-79.

[31]. V. Vijayan \& K. Balaraman, Metabolites of fungi and actinomycetes active against mosquito larvae. Indian J. Med. Res. [A], 93, $1991,115-117$.

[32]. S. Gupta, C. Montlor \& Y.S. Hwang, Isolation of novel Beauvericin Analogsfrom the fungus Beauveria bassiana. J. Nat. Prod. (Lloydia), 58, 1995, 733-738.

[33]. J. Weiser, \& V. Matha, The insecticidal activity of cyclosporins on mosquitolarvae. J. Invertebr. Pathol.51, 1988, 92-93.

[34]. J.F. Grove\&M. Pople, The insecticidal activity of beauvericin and theenniatincomplex. Mycopathologia, 70, 1980, 103-105.

[35]. D.W. Roberts, Fungal infections of mosquitoes, In: Le controle des moustiques/Mosquito control (Eds.: A. Aubin, J-P. Bourassa, S. Belloncik, M. Pellissier, \& E. acoursiere).Univ. Quebec Press, Quebec. 1974, 143-193.

[36]. S.B. Krasnoff, S. St. Gupta, R.J. Leger and J.A.A. Renwick, Antifungal andinsecticidal properties of the efrapeptins: metabolites of the fungus Tolypocladium niveum. J. Invertebr. Pathol. 58, 1991, 180-188.

[37]. B. Amini, L. Ibrahim and T.M. Butt, Antifeedant properties of destruxins and their use with the entomogenous fungus Metarhizium anisopliae for improved control of crucifer pests. Biocont. Sci. Technol. 9, 1999, 487-498.

[38]. D. Abendstein and H. Strasser, Consideration on toxic metabolites produced by Beauveria brongniartii. In: S. Kelley (ed), Integrated Control of Soil Pests Subgroup "Melolontha'. IOBC/WRP Bulletin, Dijon. 2000,99-105. 
[39]. A.R. Bandani, B.P.S. Khambay, J. Faull, R. Newton, M. Deadman and T.M. Butt, Production of efrapectins by Tolypocladium species (Deuteromycotina: Hyphomycetes) and evaluation of their insecticidal and antimicrobial properties. Mycol. Res. 104, 2000, 537-544.

[40]. H. Strasser, A. Vey and T. Butt, Are there any risks in using entomopathogenic fungi for pest control, with particular reference to the bioactive metabolites of Metarhizium, Tolypocladium and Beauveria species? Biocont. Sci. Technol. 10, $2000,717-735$.

Table 1: Antimosquito Larval Activity of Dichloromethane Extract (DCM)

\begin{tabular}{|c|c|c|c|c|c|c|c|c|c|}
\hline Time/Extract & Set & $\mathrm{C}-1$ & $\begin{array}{l}1 \mathrm{ml} \\
(7.5 \mathrm{mg})\end{array}$ & $\mathrm{C}-2$ & $\begin{array}{l}2 \mathrm{ml} \\
(15 \mathrm{mg})\end{array}$ & $\mathrm{C}-3$ & $\begin{array}{l}3 \mathrm{ml} \\
(22.5 \mathrm{mg})\end{array}$ & C-4 & $\begin{array}{l}4 \mathrm{ml} \\
(30 \mathrm{mg})\end{array}$ \\
\hline \multirow{5}{*}{ 11:35 a.m } & 1 & - & - & - & - & - & - & - & - \\
\hline & 2 & - & - & - & - & - & - & - & - \\
\hline & 3 & - & - & - & - & - & - & - & - \\
\hline & 4 & - & - & - & - & - & - & - & $\begin{array}{l}\text { Slow } \\
\text { activity }\end{array}$ \\
\hline & 5 & - & - & - & - & - & - & - & - \\
\hline \multirow{5}{*}{ 12:05 a.m } & 1 & - & - & - & $\begin{array}{l}\text { Slow } \\
\text { activity }\end{array}$ & - & $\begin{array}{l}\text { Slow } \\
\text { activity }\end{array}$ & - & 1 Death \\
\hline & 2 & - & - & - & - & - & - & - & - \\
\hline & 3 & - & - & - & - & - & - & - & - \\
\hline & 4 & - & - & - & - & - & - & - & - \\
\hline & 5 & - & - & - & - & - & - & - & - \\
\hline \multirow{5}{*}{$12: 35$ a.m } & 1 & - & - & - & $\begin{array}{l}\text { Slow } \\
\text { activity }\end{array}$ & - & $\begin{array}{l}\text { Slow } \\
\text { activity }\end{array}$ & - & $\begin{array}{l}\text { Slow } \\
\text { activity }\end{array}$ \\
\hline & 2 & - & - & - & $\begin{array}{l}\text { Slow } \\
\text { activity }\end{array}$ & & $\begin{array}{l}\text { Slow } \\
\text { activity }\end{array}$ & & $\begin{array}{l}\text { Slow } \\
\text { activity }\end{array}$ \\
\hline & 3 & - & - & - & $\begin{array}{l}\text { Slow } \\
\text { activity }\end{array}$ & - & - & - & - \\
\hline & 4 & - & $\begin{array}{l}\text { Slow } \\
\text { activity }\end{array}$ & - & $\begin{array}{l}\text { Slow } \\
\text { activity }\end{array}$ & - & $\begin{array}{l}\text { Slow } \\
\text { activity }\end{array}$ & - & $\begin{array}{l}\text { Slow } \\
\text { activity }\end{array}$ \\
\hline & 5 & - & - & - & $\begin{array}{l}\text { Slow } \\
\text { activity }\end{array}$ & - & $\begin{array}{l}\text { Slow } \\
\text { activity }\end{array}$ & - & $\begin{array}{l}\text { Slow } \\
\text { activity }\end{array}$ \\
\hline \multirow{5}{*}{ 01:05 a.m } & 1 & - & 2 Death & - & 2 Death & - & 6 Death & - & 9 Death \\
\hline & 2 & - & 2 Death & - & 2 Death & - & 6 Death & - & 9 Death \\
\hline & 3 & - & 2 Death & - & 2 Death & - & 6 Death & - & 8 Death \\
\hline & 4 & - & 2 Death & - & 2 Death & - & 6 Death & - & 9 Death \\
\hline & 5 & - & 2 Death & - & 2 Death & - & 6 Death & - & 9 Death \\
\hline $\begin{array}{l}\text { Larval Death in } \\
\%\end{array}$ & & $\begin{array}{l}\text { No } \\
\text { Death }\end{array}$ & $20 \%$ & $\begin{array}{l}\text { No } \\
\text { Death }\end{array}$ & $20 \%$ & $\begin{array}{l}\text { No } \\
\text { Death }\end{array}$ & $60 \%$ & $\begin{array}{l}\text { No } \\
\text { Death }\end{array}$ & $\begin{array}{l}100 \% \\
(80 \% \\
\text { only for } \\
\text { Set 3 of } \\
01: 05 \\
\text { a.m) }\end{array}$ \\
\hline
\end{tabular}

Where, C-1, C-2, C-3, and C-4 are control 1,2,3 and 4 respectively.

Table 2: Antimosquito Larval Activity of Chloroform Extract (CHL)

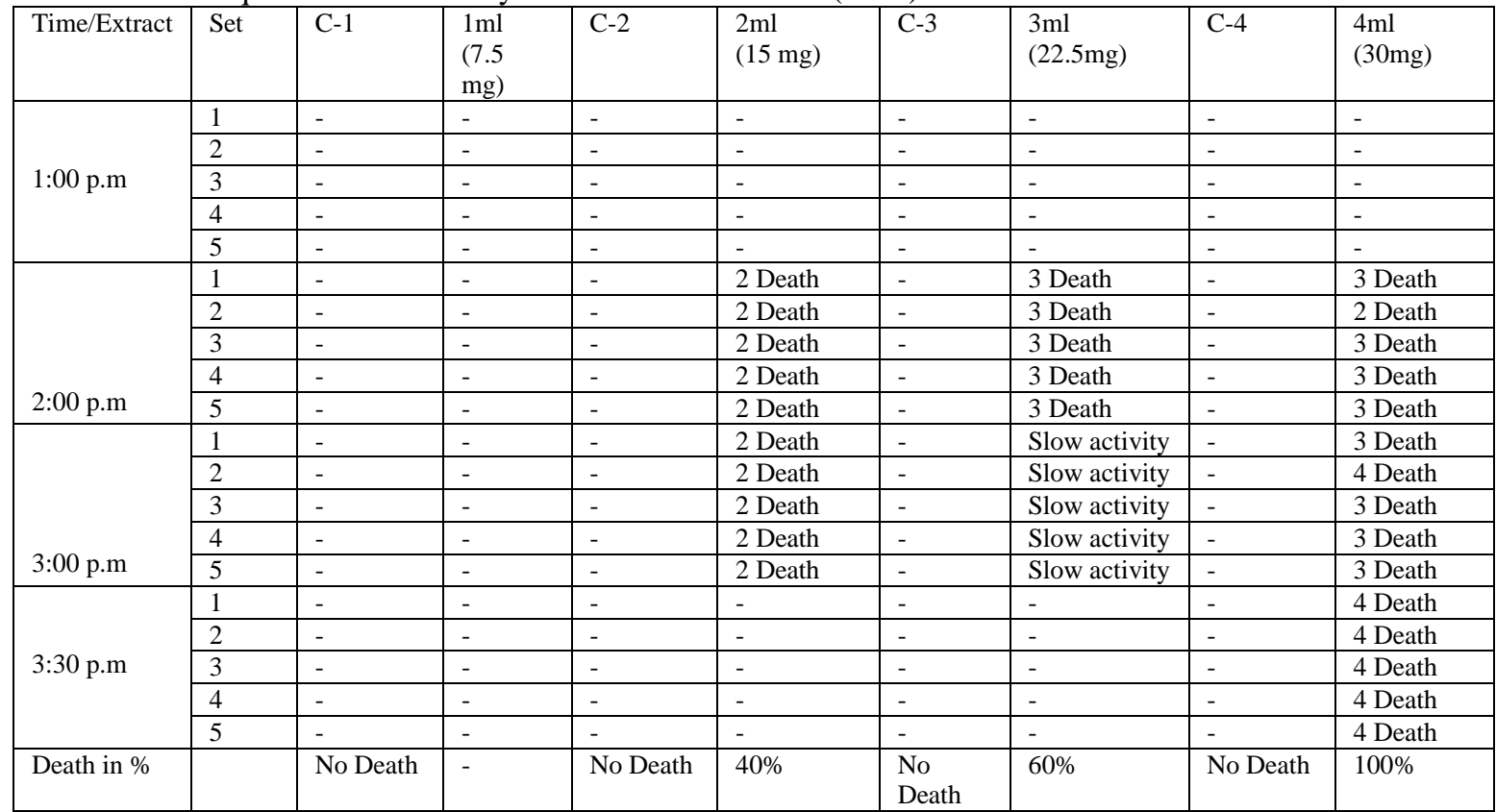

Where, C-1, C-2, C-3, and C-4 are control 1,2,3 and 4 respectively. 
Fig. 1: Larval Death In Percentage With Respect To Dichloromethane Extract (DCM) Concentration in mg.

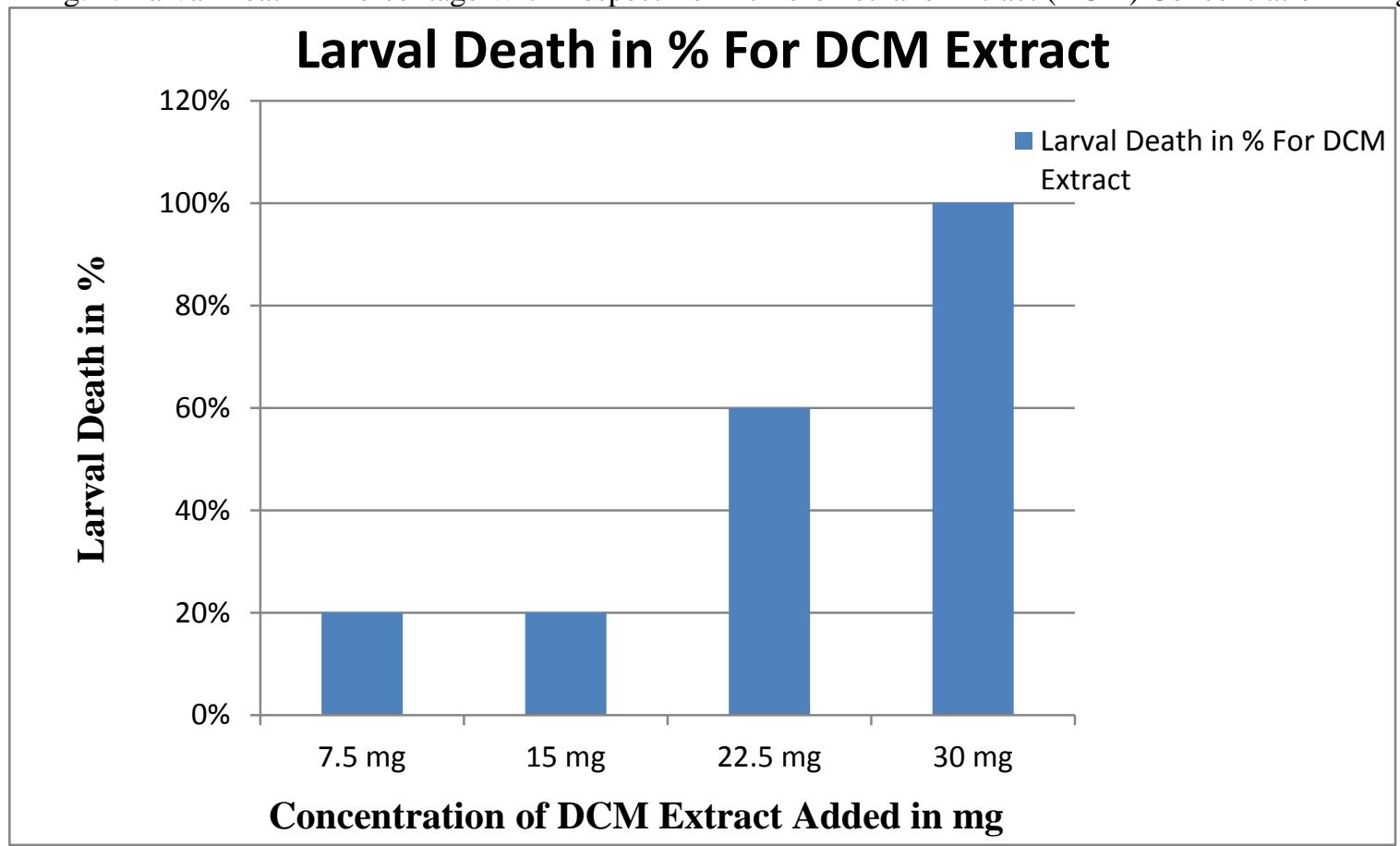

Fig. 2: Larval Death In Percentage With Respect To Chloroform Extract (CHL) Concentration in mg.

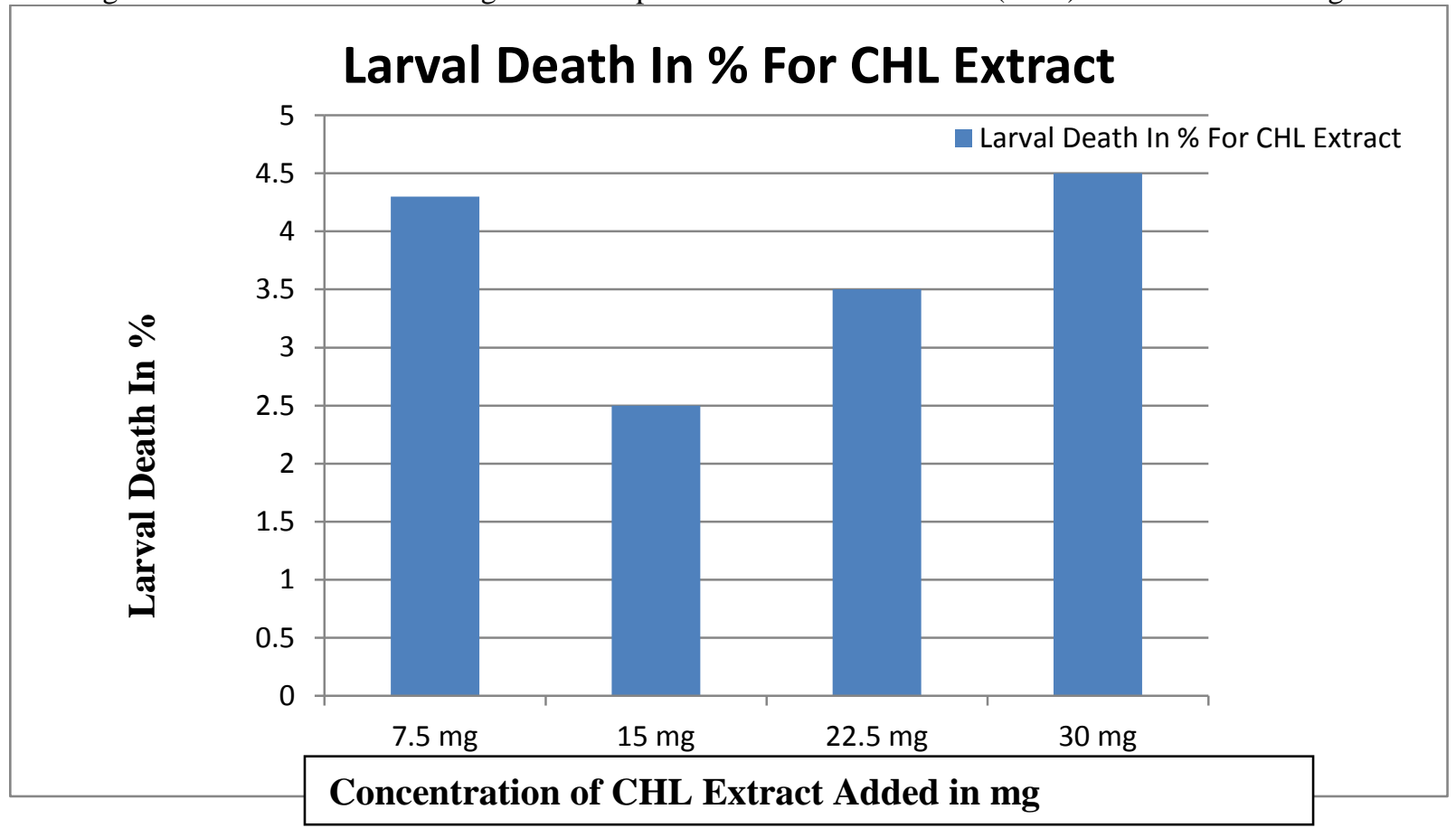

